\title{
Slope Stability Assessment and Underground Mine Design Analysis of Achibo-Sombo Underground Conventional Coal Mine, Southwest Ethiopia
}

\author{
Mulata Haftu ${ }^{1}$, Bheemalingeswara Konka ${ }^{1}$, Kifle Woldeargay ${ }^{1}$ and Asmelash Abay ${ }^{1 *}$ \\ ${ }^{1}$ Department of Earth Science, College of Natural and Computational Sciences, P.O.Box.3066, \\ Mekelle University, Mekelle, Ethiopia
}

\begin{abstract}
We report the slope stability assessment and underground mine design analysis results for the first of its kind conventional Achibo-Sombo underground coal mine from Ethiopia. Based on the RQD, RMR and Q classification system, the rocks in the mine are of poor to fair rock quality and are classified into category I $(<10 \mathrm{MPa})$, category II $(10-25 \mathrm{MPa})$, and category III ( $>25 \mathrm{MPa})$. Joint space and aperture are ranging from few $\mathrm{mm}$ to $\mathrm{cm}$ with E-W, NNW-SSE and N-S orientations and low to very low persistence from $50 \mathrm{~cm}$ to $2 \mathrm{~m}$. The factor of safety calculated using CMRI, Salamon-Munro, Greenwald, Obert and Duvall, and Bieniawsk methods for the existing pillars for category I is $1.37,4.39,2.21,3.58$, 4.76; category II 2.25, 4.39, 7.76, 12.52, 16.72; and category III 3.21, 4.39, $13.72,22.26,29.58$ respectively. The factor of safety calculated again for the newly proposed design using the same methods is $1.05,3.83,1.91$, $2.99,3.8$ for category I; $1.65,3.17,5.48,8.55,10.02$ for category II and $2.20,2.63,7.91,8.26,14.25$ for category III respectively. The extraction percentage has increased from $24.2 \%$ (for the existing) to $31 \%, 41 \%$ and $52 \%$ for I, II and III categories respectively.
\end{abstract}

\section{Introduction}

Ethiopia is gifted with many mineral resources. One such resource is coal. Exploration activities for coal deposits in Ethiopia have started around 1940s. Occurrence of the $4 \mathrm{~m}$ thick coal at Yayu basin (part of the research) was reported by EMDE [1]. Review on coal reserve estimation of Yayu area was carried out by many workers [2]. In the Yayu area about $250 \times 10^{6}$ tons of coal is estimated as A and B reserve categories in $41 \mathrm{~km}^{2}$ area [2]. About 178,576,000 tons is estimated as intrinsic economic resource for Wattete Mine field and coal rank determined to be lignite to sub- bituminous and medium to high volatile coal [2]. Though, coal mining in Achibo-Sombo (study area) is carried out by underground mining method using conventional approach, the safety of the mine and mine design, studies on structural, geotechnical and pillar design analysis are not yet done and remained a gap. The study includes, evaluation of pillar in terms size, pillar shape, strength and

\footnotetext{
${ }^{*}$ Corresponding author: asmelashby@yahoo.com
} 
geometry, correlation of geological structures and investigate their effect on the mine, rock mass characterization and classify the rocks, study geotechnical properties of rocks, determine the safety factors and calculate the extraction ratio.

The study area is located in south western Ethiopia and bounded by geographic coordinates of $8^{0} 20^{\prime} 0^{\prime}$ ' to $8^{0} 25^{\prime} 0^{\prime}$ ' $\mathrm{N}$ and $35^{0} 56^{\prime} 0^{\prime}$ ' to $36^{0} 3^{\prime} 0^{\prime}$ ' $\mathrm{E}$ (Figure 1).

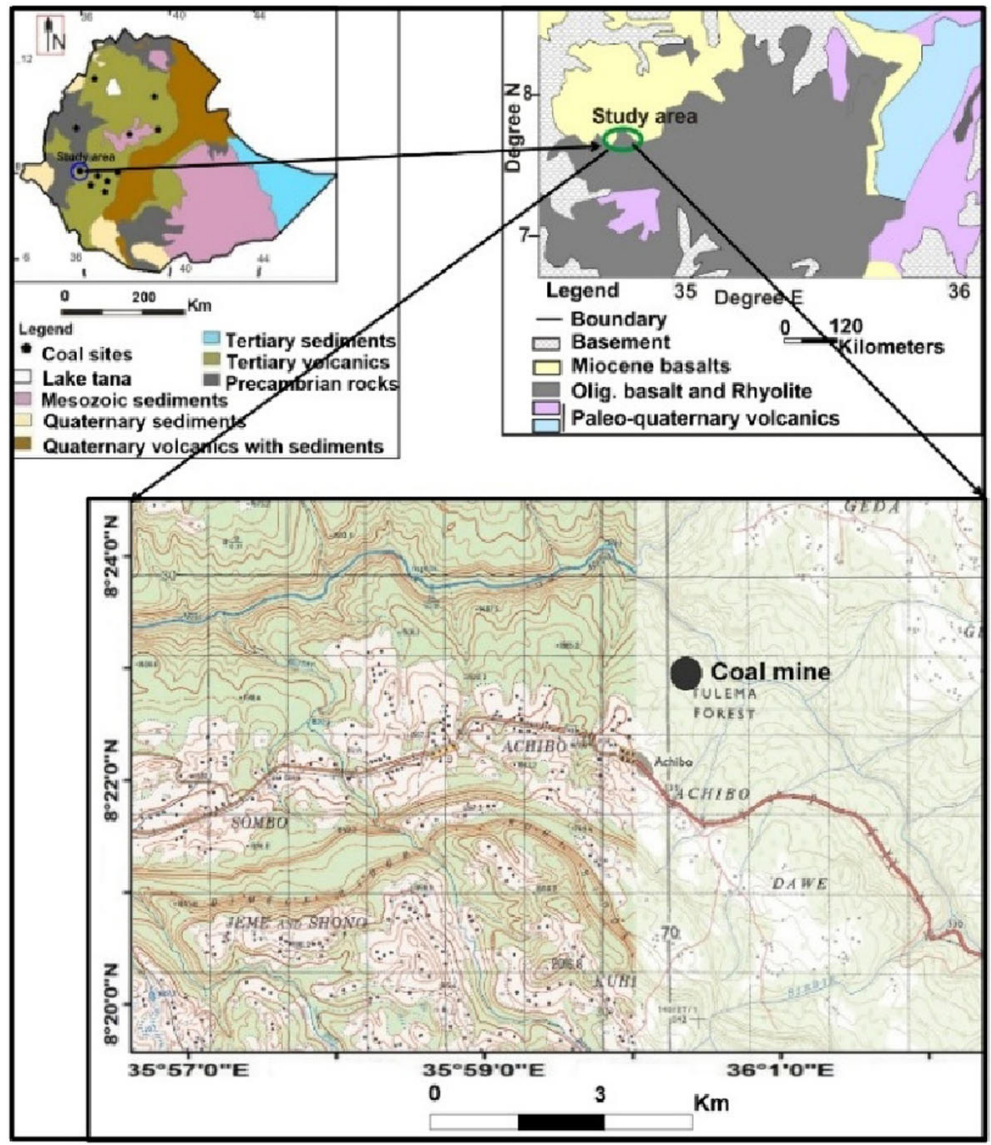

Fig. 1. Location map of the study area with reference to (A) coal map of Ethiopia (B) Regional geological map of southwestern Ethiopia (C) study area

The Achilo-Sombo mine is an underground conventional coal mine first of its kind in Ethiopia. It has three main parallel openings. At present only two are in operation, the third one is used for drainage purpose.

Published literature is very scanty for the Achilo-Sombo underground coal mine, except the unpublished reports and maps related to geology, geotechnic and mining prepared by various exploration companies and Geological Survey of Ethiopia.

\section{Geology of the Study Area}

The area consists of Neoproterozoic basement rocks at the base and overlain by Tertiary volcanics and coal-bearing sedimentary rocks (Figure 2). The volcanic rocks are divided into two, lower and upper volcanics based on age, stratigraphic setup and geochemical variations [1]. Upper volcanics include aphanitic basalt, porphyritic basalt, vesicular basalt, 
tuffs and amygdaloidal basalt. Sedimentary rocks occur between upper and lower volcanic and consists of carbonaceous shale, oil shale, sandstone, mudstone, claystone and coal.

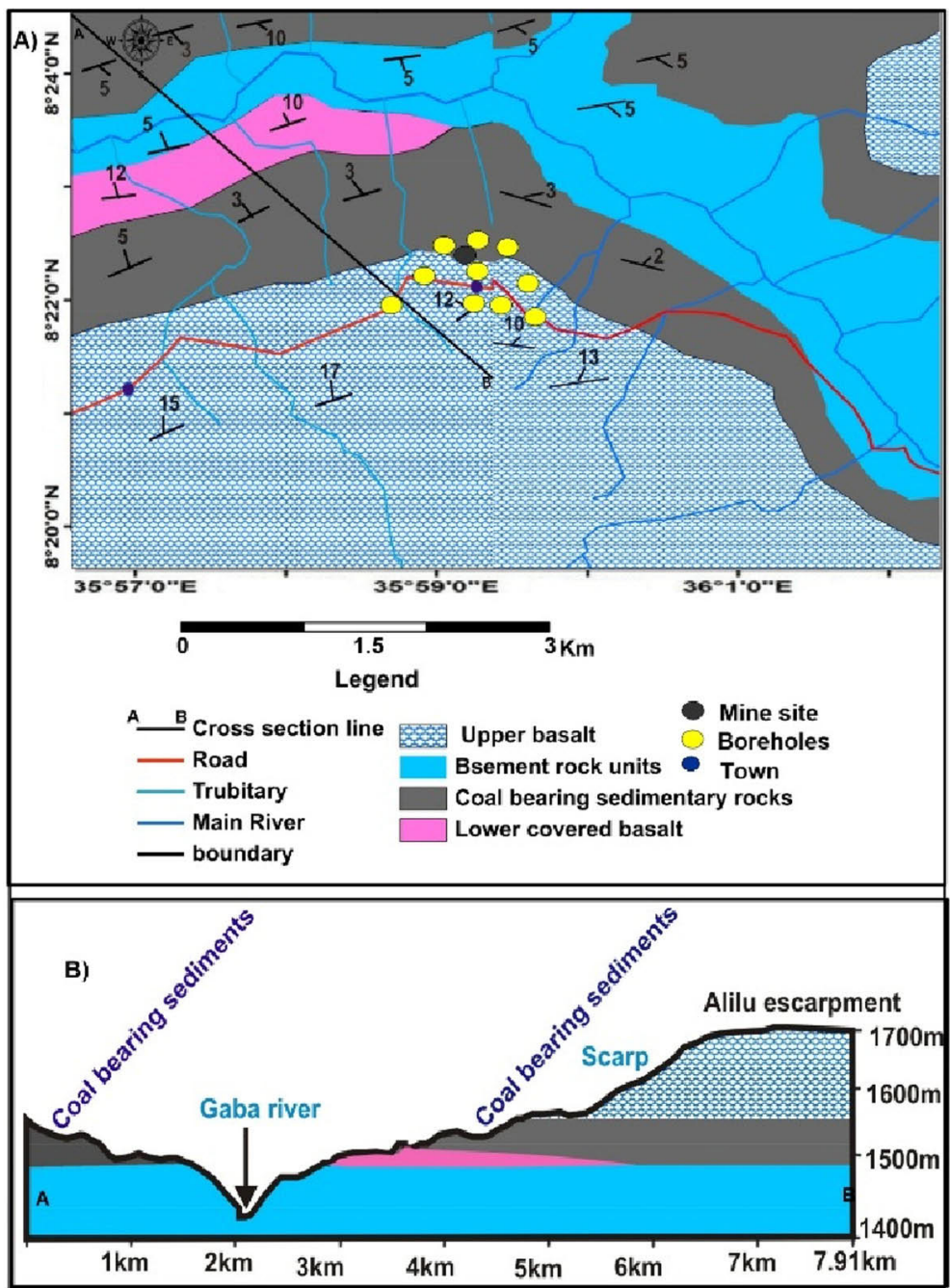

Fig. 2 (A) Geological map (B) cross section profile along the line A-B of the study area

\section{Methodology}

A field work was planned in February 2016 and a geological and structural map for the study area was prepared (Figure 2). All the geological units were properly studied and recorded. The borehole logs [1] were also studied to understand the subsurface and the core rock samples were collected for geotechnical analysis. The mine site was visited at different openings and studied the pillars. Rock types, number of seams, inclination of seams, pillar geometry and structures (faults, folds, structural contacts and fractures) were studied. Geological data related to coal seams location, depth of seams, seam thickness etc was collected. Mine data related to floor, roof, pillar positions, pillar dimensions and geometries etc were collected. Structural measurements were carried out and recorded them in detail. 50 rock samples from surface, core (representing all lithologies) and in the mine from 
pillar, roof and floor were collected to study their geotechnical properties. Out of these, 10 samples (4 from roof and 3 from floor and 3 from intermediate) were selected for compressive strength tests and conducted in Mekelle University, Ethiopia.

Rock mass was classified and characterized based on Rock Quality Designation (RQD), Rock Mass Rating (RMR) and the Rock Mass Quality System (Q-System). This is to evaluate strength of the pillars, roofs and floors as well as the support system. Based on different methods CMRI [3], Salamon-Munro [4], Greenwald [5], Obert-Duvall [6], and Bieniawski [7], factor of safety, pillar load and extraction percentage were calculated and evaluated to understand the stability of the mine. Different software packages like Rockwork, Surpack Minex 6.5, Global Mapper12, Surfer10, ARC GIS10 and Mapinfo 8.5 were employed for data processing.

\section{Geological Structures}

Different geological structures observed in the study area. The structures studied were normal faults (trending ENE-WSW, E-W, and N-S), strike slip faults, columnar joints, folds, weak planes and quartz veins. The structural data is presented in figure 3 .

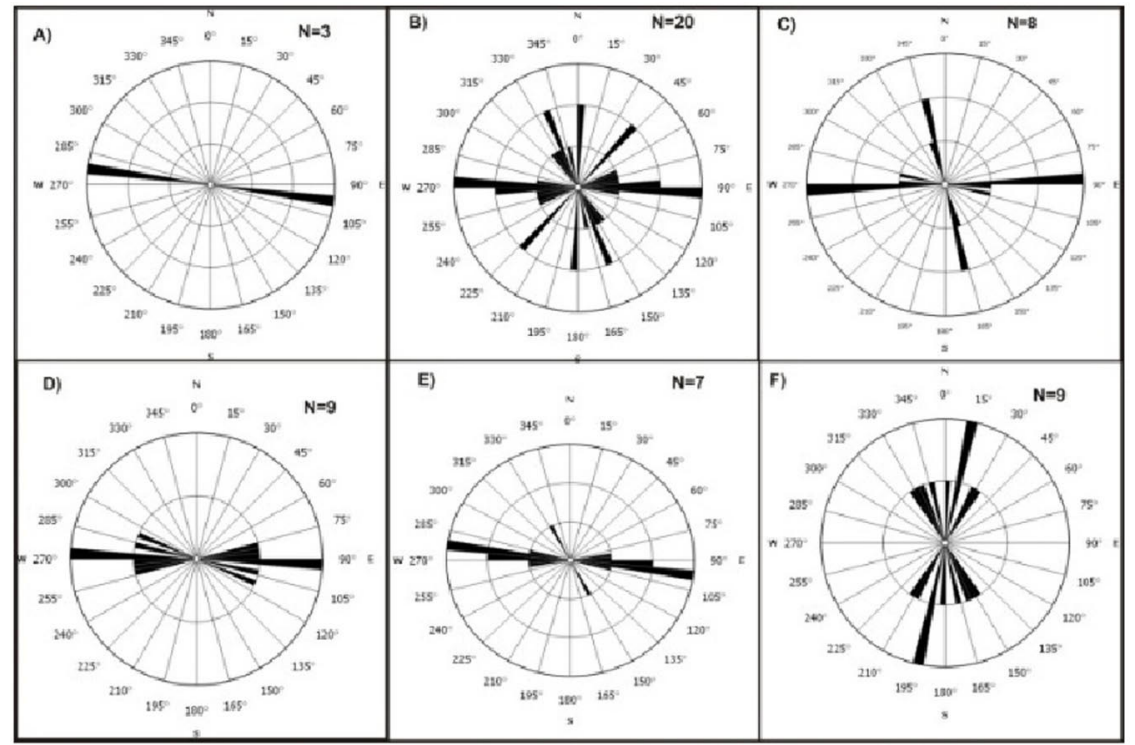

Fig. 3. Rose diagram showing (a) mining direction, (b) general joints and fractures orientation, (c) fault orientation, (d) lineament orientation (E) bed orientation, (F) quartz veins orientation.

\section{Results and Discussion}

The compressive strength results for the selected samples are given in table 1. Depending on the strength value the coal mine can be classified into three categories, I, II and III. Category I of $<10 \mathrm{MPa}$ strength, category II between 10 to $25 \mathrm{MPa}$ strength and category III having $>25 \mathrm{MPa}$ strength.

Table 1. Compressive strength of the rock sample

\begin{tabular}{|l|l|l|l|l|l|l|l|}
\hline S. No & $\begin{array}{l}\text { Sample } \\
\text { Code }\end{array}$ & $\begin{array}{l}\text { Area } \\
\left(\mathbf{c m}^{2}\right)\end{array}$ & $\begin{array}{l}\text { Area } \\
\left(\mathbf{m}^{2}\right)\end{array}$ & $\begin{array}{l}\text { Weight } \\
(\mathbf{k g})\end{array}$ & $\begin{array}{l}\text { Load } \\
(\mathbf{K N})\end{array}$ & $\begin{array}{l}\text { load/area } \\
\left(\mathbf{K N} / \mathbf{m}^{2}\right)\end{array}$ & $\begin{array}{l}\text { Compressive } \\
\text { strength(MPa) }\end{array}$ \\
\hline 1 & FBH-5-1 & $13^{*} 7(91)$ & 0.0091 & 0.731 & 155.12 & 17046.15 & 17.046 \\
\hline
\end{tabular}




\begin{tabular}{|l|l|l|l|l|l|l|l|}
\hline 2 & FBH-3-1 & $7.3 * 7(51.1)$ & 0.00511 & 0.416 & 111.7 & 21859.09 & 21.86 \\
\hline 3 & RBH-7-4 & $11 * 5.3(58.3)$ & 0.00583 & 0.411 & 45.01 & 7118.35 & 7.12 \\
\hline 4 & RBH-8-3 & $11 * 5.3(58.3)$ & 0.00583 & 0.633 & 20.4 & 3499.14 & 3.5 \\
\hline 5 & AMFVE2 & $15 * 12(180)$ & 0.018 & 0.818 & 117 & 6500 & 6.5 \\
\hline 6 & AMFMT1 & $10^{*} 6.3(63)$ & 0.0063 & 0.493 & 196 & 31111.1 & 31.11 \\
\hline 7 & AMFWD1 & $10^{*} 4.5(45)$ & 0.0045 & 0.96 & 169.52 & 59893.3 & 37.67111 \\
\hline 8 & AMRVE1 & $11 * 11(121)$ & 0.012 & 0.833 & 48.54 & 4045 & 4.045 \\
\hline 9 & AMRMT1 & $10^{*} 7.5(75)$ & 0.0075 & 0.847 & 39.23 & 5230.67 & 5.23067 \\
\hline 10 & AMRWD1 & $14^{*} 6(84)$ & 0.0084 & 0.563 & 57.17 & 6805.05 & 6.80505 \\
\hline
\end{tabular}

The average compressive strength values for the selected samples are given in table 2 and average values for pillars width, length and height are given in table 3 .

Table 2. Average compressive strength value for three categories.

\begin{tabular}{|l|c|c|c|}
\hline & Category I & Category II & Category III \\
\hline Average Compressive strength & 5.53 & 19.45 & 34.39 \\
\hline
\end{tabular}

Table 3. Average pillar dimensions in the underground coal min

\begin{tabular}{|c|c|c|c|}
\hline Pillar width & Pillar length & Pillar height & Average difference between pillars \\
\hline $12.13 \mathrm{~m}$ & $12.9 \mathrm{~m}$ & $1.99 \mathrm{~m}$ & $1.8 \mathrm{~m}$ \\
\hline
\end{tabular}

Given conditions of pillar geometry to calculate pillar loading:

- $\mathrm{L}_{\mathrm{P}}=12.9 \mathrm{~m}, \mathrm{~W}_{\mathrm{P}}=12.13 \mathrm{~m}, \mathrm{~W}_{\mathrm{O}}=1.8 \mathrm{~m}, \mathrm{~h}=1.99 \mathrm{~m}$ where $\mathrm{L}_{\mathrm{P}}$ is average pillar length, $\mathrm{W}_{\mathrm{P}}$ is average pillar width, $\mathrm{W}_{\mathrm{O}}$ is difference between pillars (width of opening), $\mathrm{h}$ is average pillar height (Table 3)

- Average thickness of coal seam is $1.67 \mathrm{~m}$.

- Depth of coal seam: $105 \mathrm{~m}$

Compressive strength of the coal sample tested in laboratory: 5.53,19.45 and $34.39 \mathrm{MPa}$ for category I, category II and category II respectively.

Based on the above geometries and according different workers [8][9][10] pillar loading is calculated and given below.

$\boldsymbol{\sigma}_{\text {avg }}=\left(\mathrm{L}_{\mathrm{P}}+\mathrm{W}_{\mathrm{O}}\right) \times\left(\mathrm{W}_{\mathrm{P}}+\mathrm{W}_{\mathrm{O}}\right) \times \sigma \mathrm{v} /\left(\mathrm{L}_{\mathrm{P}} \mathrm{x} \mathrm{W}_{\mathrm{P}}\right)=$ stress (load) on the pillar due to over burden

$\boldsymbol{\sigma} \mathbf{v}$ is vertical stress $=\mu \times \mathrm{H}$ where

$\mu=$ average density of overburden rock strata $(2247 \mathrm{Kg} / \mathrm{m} 3$, source from the company table of physical and mechanical Properties of rocks) and $\mathrm{H}$ is Depth of coal seam.

$\boldsymbol{\sigma} \mathbf{v}=105 \mathrm{~m} \times 2247 \mathrm{Kg} / \mathrm{m}^{3}$

$\sigma v=2.35 \mathrm{MPa}$

$\sigma_{\text {avg }}=\left(\mathrm{L}_{\mathrm{P}}+\mathrm{W}_{\mathrm{O}}\right) \times\left(\mathrm{W}_{\mathrm{P}}+\mathrm{W}_{\mathrm{O}}\right) \times \sigma \mathrm{v} /\left(\mathrm{L}_{\mathrm{P}} \times \mathrm{W}_{\mathrm{P}}\right)$

$\sigma_{\text {avg }}=(12.9 \mathrm{~m}+1.8) \times(13.13+1.8) \times 2.35 \mathrm{MPa} /(12.9 \times 12.13)$

$\boldsymbol{\sigma}_{\text {avg }}=3.29 \mathrm{MPa}=$ stress (load) on the pillar due to overburden.

\subsection{Pillar Strength Formulas}

The following researchers have calculated the pillar strength based on laboratory tests, insitu tests, and case histories and said that the strength of the pillar is dependent on compressive strength of the pillar. 


\subsubsection{CMRI formula}

Indian coal mine regulation [3] has developed the following formula:

$\sigma_{\mathrm{p}}=\left(0.27 \times \sigma \mathrm{c} \times \mathrm{h}^{-0.36}\right)+(\mathrm{H} / \mathbf{1 6 0}(\mathrm{wp} / \mathrm{h}-1))$

where, $\sigma_{\mathrm{p}}=$ Pillar strength $(\mathrm{MPa}), \sigma \mathrm{c}=$ compressive strength $(\mathrm{MPa}), \mathrm{h}=$ working height or pillar height (in $\mathrm{m}), \mathrm{H}=$ depth of cover $(\mathrm{m}), \mathrm{w}=$ pillar width $(\mathrm{m})$.

Since, there are three categories depending on compressive strength it is calculated separately as follows:

Category I

$\sigma_{\mathrm{p}}=\left(0.27 \times 5.53 \mathrm{MPa} \times 1.99 \mathrm{~m}^{-0.36} \mathrm{~m}\right)+(105 \mathrm{~m} / 160(12.13 \mathrm{~m} / 1.99 \mathrm{~m}-1))$

- $\sigma_{\mathrm{p}}=4.505 \mathrm{MPa}$

Category II

$\sigma_{\mathrm{p}}=\left(0.27 \times 19.45 \mathrm{MPa} \times 1.99 \mathrm{~m}^{-0.36} \mathrm{~m}\right)+(105 \mathrm{~m} / 160(12.13 \mathrm{~m} / 1.99 \mathrm{~m}-1))$

- $\quad 7.43 \mathrm{MPa}$

Category III

$\sigma_{\mathrm{p}}=\left(0.27 \times 34.39 \mathrm{MPa} \times 1.99 \mathrm{~m}^{-0.36} \mathrm{~m}\right)+(105 \mathrm{~m} / 160(12.13 \mathrm{~m} / 1.99 \mathrm{~m}-1))$

- $\quad 10.58 \mathrm{MPa}$

\subsubsection{Salamon-Munro Formula}

Salamon and Munro [4] proposed the following pillar strength formula.

$$
\sigma_{\mathrm{p}}=7.2 \times \mathbf{W}_{\mathbf{p}}^{0.46} / \mathbf{h}^{0.66}
$$

Where, $\sigma p$ the strength of the pillar and the pillar dimensions $\mathrm{W}_{\mathrm{P}}$ and $\mathrm{h}$ are width and height respectively. Since this formula does not depend on compressive strength the pillar strength value for the three categories are the same and calculated as follows.

$$
\sigma_{\mathrm{p}}=7.2\left(12.13^{0.46} / 1.99^{0.66}\right)
$$

- $\sigma_{\mathrm{p}}=14.45 \mathrm{MPa}$

\subsubsection{Greenwald formula}

Greenwald [5] formulated the following formula to calculate the coal pillar strength of underground coal mining.

$$
\sigma_{\mathrm{p}}=\mathbf{0 . 6 7} \mathrm{K} \sqrt{w p} / \mathbf{h}^{0.83}
$$

Where $\sigma_{\mathrm{p}}$ is the pillar strength, $\mathrm{k}$ is the strength of coal sample, $\mathrm{w}_{\mathrm{p}}$ is the pillar width and $\mathrm{h}$ is the pillar height. The calculated pillar strength for the three categories is evaluated below:

$$
\begin{aligned}
& \text { Category I } \\
& \mathrm{C}_{\mathrm{P}}=0.67 \cdot 5.53 \sqrt{12.13} / 1.99^{0.83} \\
& \text { Category II } \\
& \mathrm{C}_{\mathrm{P}}=7.28 \mathrm{MPa} \\
& \text { - } \quad 25.54 \cdot 19.45 \sqrt{12.13} / 1.99^{0.83} \\
& \text { Category III } \\
& \mathrm{C}_{\mathrm{P}}=0.67 \cdot 34.39 \sqrt{12.13} / 1.99^{0.83} \\
& \cdot \quad 45.33 \mathrm{MPa}
\end{aligned}
$$




\subsubsection{Obert and Duvall formula}

Obert and Duvall [6] proposed the following formula:

$$
\sigma_{\mathrm{p}}=\mathbf{C}_{\mathbf{1}}[\mathbf{0 . 7 7 8}+\mathbf{0 . 2 2 2} \mathrm{W} / \mathbf{h}]
$$

Where $\sigma_{\mathrm{p}}$ : pillar strength, $\mathrm{c}_{1}$ : the compressive strength of specimens, $\mathrm{W}$ : width of the pillar and h: height of the pillar. Because the coal mine has classified in three categories based on strength the pillar strength can be calculated as follows:

Category I

$$
\begin{aligned}
& \sigma_{\mathrm{p}}=5.53 \mathrm{MPa}[0.778+0.222(12.13 \mathrm{~m} / 1.99 \mathrm{~m})] \\
& \text { • } \quad \sigma_{\mathrm{p}=11.78 \mathrm{MPa}} \\
& \text { Category II } \\
& 19.45 \mathrm{MPa}[0.778+0.222(12.13 \mathrm{~m} / 1.99 \mathrm{~m})] \\
& \text { • } \quad 41.2 \mathrm{MPa} \\
& \text { Category III } \\
& 34.39 \mathrm{MPa}[0.778+0.222(12.13 \mathrm{~m} / 1.99 \mathrm{~m})] \\
& \text { • } \quad 73.25 \mathrm{MPa}
\end{aligned}
$$

\subsubsection{Bieniawski formula}

The general normalized form of the Bieniawski [7] equation is

$$
\sigma_{\mathrm{p}}=\boldsymbol{\sigma} \mathbf{1}(\mathbf{0 . 6 4}+\mathbf{0 . 3 6}(\mathrm{w} / \mathrm{h}))
$$

Where $\sigma_{\mathrm{p}}$ is pillar strength, $\mathrm{w}$ is pillar width, $\mathrm{h}$ is pillar height, and $\sigma 1$ strength of the coal specimen.

Category I

$$
\sigma_{\mathrm{p}}=5.53 \mathrm{MPa}(0.64+0.36(12.13 / 1.99)
$$$$
\text { - } \sigma_{\mathrm{p}}=15.67 \mathrm{MPa}
$$

Category II

$\sigma_{\mathrm{p}}=19.45 \mathrm{MPa}(0.64+0.36(12.13 / 1.99)$

\begin{tabular}{|c|c|c|c|c|}
\hline \multirow[t]{3}{*}{ A) } & \multirow{3}{*}{ Method } & \multicolumn{3}{|c|}{ Factor of safety } \\
\hline & & \multicolumn{3}{|c|}{ Category } \\
\hline & & I & II & III \\
\hline 1 & CMRI & 1.37 & 2.25 & 3.21 \\
\hline 2 & Salamon-Munro Formula & 4.39 & 4.39 & 4.39 \\
\hline 3 & Greenwald & 2.21 & 7.76 & 13.72 \\
\hline 4 & Obert and Duvall & 3.58 & 12.52 & 22.26 \\
\hline 5 & Bieniawski & 4.76 & 16.72 & 29.58 \\
\hline
\end{tabular}

- $\quad 55.04 \mathrm{MPa}$

Category III

$\sigma_{\mathrm{p}}=34.39 \mathrm{MPa}(0.64+0.36(12.13 / 1.99)$

- $\quad 97.32 \mathrm{MPa}$

\section{Factor of safety}

The safety factor for the existing mine design is calculated using the below mentioned formula and the values are given table $4 \mathrm{~A}$.

Factor of safety $=\boldsymbol{\sigma} \mathbf{p} / \boldsymbol{\sigma}_{\text {avg }}$

Table 4. Factor of safety for the existing pillar width of $12.13 \mathrm{~m}$ and $\mathrm{b}$ ) Factor of safety for the new design (pillar width of $9 \mathrm{~m}, 6 \mathrm{~m}$ and $4 \mathrm{~m}$ ) 


\begin{tabular}{|l|l|c|c|c|}
\hline \multicolumn{1}{|c|}{ Method } & I & II & III \\
\hline B) & & 1.05 & 1.65 & 2.20 \\
\hline 1 & CMRI & 3.83 & 3.17 & 2.63 \\
\hline 2 & Salamon-Munro Formula & 1.91 & 5.48 & 7.91 \\
\hline 3 & Greenwald & 2.99 & 8.55 & 8.26 \\
\hline 4 & Obert and Duvall & 3.8 & 10.2 & 14.25 \\
\hline 5 & Bieniawski & & & \\
\hline
\end{tabular}

\subsection{Rock mass classification of coal mine}

This work used RQD, RMR and Q system for characterization of the underground coal mine.

\subsubsection{Rock Quality Designation index (RQD)}

From core log study the RQD of the rocks were calculated [8]. The results indicate that the quality of rocks in the borehole varies with lithology and depth. Accordingly, the coalbearing sedimentary rocks together with the upper basalt rock units have very poor rock quality $(<25 \%)$. The lower basalt and basement rock units show relatively fair $(25-50 \%)$ to good $(50-75 \%)$ quality of rocks.

\subsubsection{Geotechnics Classification (RMR)}

This method considers six parameters, UCS, RQD, spacing, joint condition, groundwater condition and structures orientation. While assessing the rock masses the rating value is given for each parameter. The summation of the value of all parameters of RMR is 38 .

This indicates the underground coal mine is at the boundary between poor and fair rock quality.

\subsubsection{Rock Tunneling Quality Index (Q)}

The numerical value of the index $\mathrm{Q}$ is defined by= RQD/Jn*Jr/Ja*Jw/SRF where RQD is the Rock Quality Designation, Jn is the joint set number, Jr is the joint roughness number, $\mathrm{Ja}$ is the joint alteration number, $\mathrm{JW}$ is the joint water reduction factor, SRF is the stress reduction factor.

Using these values gives $\mathrm{Q}=0.057$ which is classified under poor to extremely poor rock quality.

\section{Extraction Ratio (R)}

Extraction ratio is the ratio of mined volumes to total volumes of the deposit and calculated using the following formula.

$$
\mathbf{R} \%=\left(1-\left(\mathbf{W}_{\mathrm{p}}^{2} /\left(\mathbf{W}_{\mathrm{p}}+\mathbf{W}_{\mathbf{0}}\right)^{2}\right) \times 100\right)
$$

Where $\mathrm{Wp}$ is average pillar width, $\mathrm{W}_{\mathrm{o}}$ is the difference between pillars (width of opening). The $\mathrm{R} \%$ calculated for the existing mine is $24.2 \%$ considering the $\mathrm{Wp}=12.13 \mathrm{~m}$ and $\mathrm{Wo}=1.8 \mathrm{~m}$. 


\section{Pillar design analysis}

This study proposes new mine design for the three categories, namely category I $(9 \mathrm{~m})$, category II $(6 \mathrm{~m})$ and category III $(4 \mathrm{~m})$ (Figures 4, 5 and 6). The factor of safety was calculated for the new design using different approaches like CMRI [3], Salamon-Munro [4], Greenwald [5], Obert and Duvall [6] and Bieniawsk [7] and the results are shown in table 4B.

As per the new design, the extraction percentage increases from the average value of $24.2 \%$ for the existing mine to $31 \%$ for category I, $41 \%$ category II and $52 \%$ category III.

The safety factor analysis thus clearly indicates that the underground mine is safe even if the pillar width is reduced as mentioned in figures 4,5 and 6.

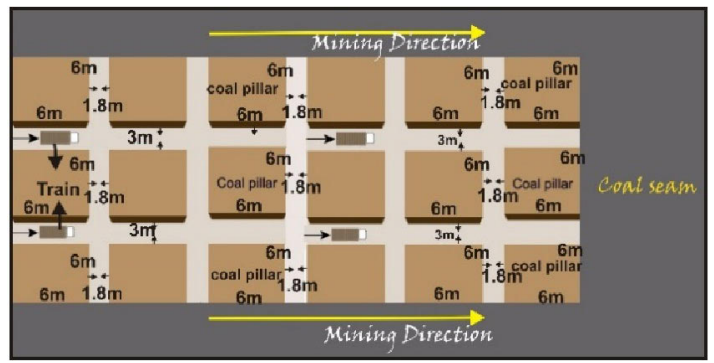

Fig. 4. New mine design with pillar width of 9m, category I.

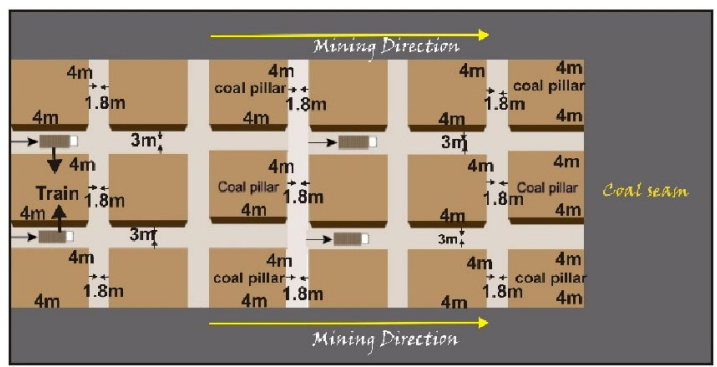

Fig. 5. New mine design with width of $6 \mathrm{~m}$, category II.

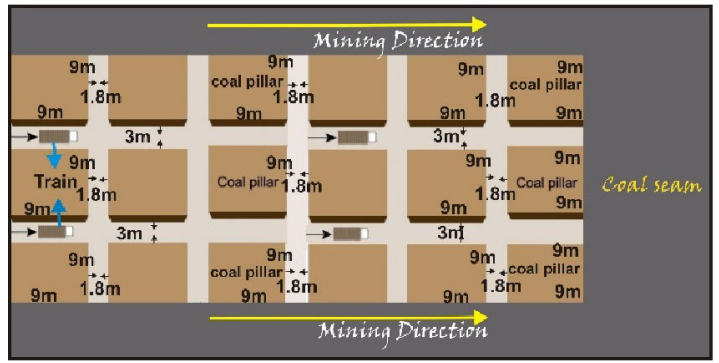

Fig. 6. New mine design with width of $4 \mathrm{~m}$, category III

\section{Conclusions}

The geological structures in the mine site are classified into two, (1) those tangential with the mining direction; and (2) perpendicular with the underground coal mine. Weak zones are causing many problems in Achibo-Sombo coal mine. These include: (1) physical displacement of coal seams, (2) reducing the stability of roof and floor in underground workings; (3) opening of pathways for the influx of water into underground workings. 
Based on rock mass RQD, RMR and Q classification, the underground coal mine rocks are characterized and classified under poor rock quality.

The factor of safety calculated for the existing pillar is $1.37,4.39,2.21,3.58$ and 4.76 for category I, 2.25, 4.39, 7.76, 12.52 and 16.72 for category II and 3.21, 4.39, 13.72, 22.26 and 29.58 for category III by CMRI, Salamon-Munro, Greenwald, Obert and Duvall and Bieniawski respectively.

The factor of safety of the new proposed pillar design is $1.05,3.83,1.91,2.99$ and 3.8 for category I, 1.65, 3.17, 5.48, 8.55 and 10.02 for category II and 2.20, 2.63, 7.91, 8.26 and 14.25 for category III by the above same method.

From this investigation the extraction percentage could increase from $24.2 \%$ to $31 \%$, $41 \%$ and 52 for the three categories respectively. This means 6.8 to $27.8 \%$ valuable coal material which could have been left as pillar could be mined. Therefore, it is recommended to use the new mine design.

\section{References}

1. Ethiopian Mine Development Enterprise (EMDE), Unpublished report (Result of Sub Surface Exploration for Coal Deposit at Achibo-Sombo, Yayu Illubabour Area) (1998).

2. H. Gebreyohannes, Unpublished report (Geological report on coal deposit extension investigation around Wattete and Yayu blocks) 1 \& 2, EIGS, Addis Ababa (2001).

3. Indian coal mine regulation (CMRI), Mine working and development sub section (1) of Act. (91) S.R.O.3419, (1957).

4. M.D.G Salamon, A.H. Munro, J. Southern African Institute of Mining and Metallurgy, 68 (1967).

5. H.P. Greenwald, H.C. Howarth, I. Hartman, Technical Paper 605 (1939), Report Investigation 3575, U.S. Bureau of Mines, (1941).

6. L. Obert, W.I. Duvall, Rock Mechanics and the Design of Structures in Rock (1967).

7. Z.T. Bieniawski. Int. J. Rock Mech. Min. Sci., 4, 325-335 (1968).

8. E. Grimstad, N. Barton, Proc. Int. Symposium Fagernes, 46 (1993).

9. D.G.F.Hedley, F. Grant, Can. Inst. Min. Metall. Bull., 65 (1972).

10. N. Krauland, P. Soder, Engineering and Mining J, 8 (1987).

11. D.U. Deere, Rock Mechanics Engineering Geology, 1, (1964) 